\title{
Morbidity as a Predictor for Participation in the Danish National Mammography Screening Program: A Cross-Sectional Study
}

This article was published in the following Dove Press journal: Clinical Epidemiology

\author{
Jakob H Viuff (D) \\ Ilse Vejborg ${ }^{2}$ \\ Walter Schwartz ${ }^{3}$ \\ Martin Bak (D) ${ }^{4}$ \\ Ellen M Mikkelsen' \\ 'Department of Clinical Epidemiology, \\ Aarhus University Hospital,Aarhus $\mathrm{N}$ \\ 8200, Denmark; ${ }^{2}$ Department of \\ Radiology, University Hospital of \\ Copenhagen Rigshospitalet, Copenhagen \\ 2100, Denmark; ${ }^{3}$ Department of \\ Radiology, Odense University Hospital, \\ Odense C 5000, Denmark; ${ }^{4}$ Department \\ of Pathology, Sydvestjysk Sygehus, Esbjerg \\ 6700, Denmark
}

Purpose: In this cross-sectional study, we evaluated the association between morbidity and participation in the prevalence round of the Danish national mammography screening program. Patients and Methods: Morbidity was assessed by the Charlson Comorbidity Index (CCI) score $(0,1-2$, and $\geq 3)$ and by 19 individual diagnoses. We retrieved data on participation from The Danish Quality Database of Mammography Screening and on diagnoses from The Danish National Patient Registry. We estimated prevalence proportion ratios (PR) with 95\% confidence intervals (CI).

Results: In total, 519,009 (79.8\%) women participated in the first national breast cancer screening round. Relative to women with a CCI score of 0 , the adjusted PRs were $0.96(95 \%$ CI: $0.95-0.96)$ for a CCI score of $1-2$ and 0.80 (95\% CI: $0.79-0.81)$ for a CCI score of $\geq 3$. Compared with no disease, the PRs for a diagnosis of the most prevalent, but less severe diseases, chronic pulmonary disease, cerebrovascular disease, diabetes I and II were 0.93 (95\% CI: 0.93-0.94), 0.96 (95\% CI: 0.94-0.96), and 0.96 (95\% CI: 0.95-0.97), respectively. Among women with low prevalent, but most severe diseases, the PRs were 0.69 (95\% CI: 0.60-0.81) for AIDS and 0.73 (95\% CI: 0.70-0.76) for metastatic solid tumor.

Conclusion: Women with a high CCI score or one severe chronic condition are less likely to participate in breast cancer screening compared to women without disease. However, these women account for a small proportion of all non-participating women. Thus, it might be most beneficial to maximize breast cancer screening participation in women with less severe although more common morbidities.

Keywords: mass screening, mammography, breast cancer, patient compliance, morbidity and comorbidity

\section{Introduction}

Breast cancer is the most common type of cancer among Danish women with approximately 4,600 women diagnosed per year. ${ }^{1}$ To reduce breast cancer-specific mortality and morbidity, women in Denmark aged 50-69 years are invited biennially to mammography screening free of charge. Local screening programs implemented in selected areas of Denmark from 1991 to 2004 preceded the national screening program starting in 2007 . $^{2}$ To ensure the effectiveness of a screening program, high participation is required. According to the European guidelines, the goal is that $75 \%$ or more of the invited women participate. ${ }^{3}$ Participation in the Danish national breast cancer screening program is being monitored annually by The Danish Quality Database of Mammography Screening. ${ }^{2}$ After exclusion of women who actively had resigned from the program,
Correspondence: Jakob H Viuff

Virus, Lifestyle and Genes, Danish Cancer Society Research Center,

Strandboulevarden 49, Copenhagen 2100 Denmark

Email jviuff@cancer.dk 
and are therefore not invited for screening, overall participation varied between $79 \%$ and $84 \%$ in the first four rounds (2008-2015). ${ }^{4,5}$ Thus, the threshold of $75 \%$ was upheld nationally, but there were notable regional differences. ${ }^{2,5}$ However, if participation is evaluated according to the number of women for whom screening was relevant (ie, all women aged 50-69 years living in Denmark) the participation rate was $75-76 \%$ throughout the first four screening rounds with pronounced regional variation $(68 \%$ to $83 \%){ }^{5}$ Thus, a considerable number of women did not participate in the national screening program.

Studies indicate that women with a high level of education, a high income, or being married are most likely to participate. ${ }^{6-8}$ Although, one Danish study showed that the educational gradient in women never participating was U-shaped. ${ }^{9}$ Multimorbidity, defined as the occurrence of multiple chronic conditions in the same individual, is a growing problem. ${ }^{10,11}$ However, few high-quality studies have examined morbidity as a predictor for participation in breast cancer screening programs and the results are mixed. ${ }^{12}$ Two studies based on self-assessed health found that women with increased morbidity had a higher participation rate compared to those without morbidity. ${ }^{6,8}$ Another study reported that even though poor self-assessed health was associated with low screening participation, having one or more chronic conditions increased participation. These women may have frequent contact with the healthcare system and therefore be more likely to be compliant. ${ }^{13}$ In contrast, a study showed that one incremental increase in the Charlson Comorbidity Index (CCI) score meant $17 \%$ less likelihood of participation. ${ }^{14}$ A recent study of breast cancer screening in one Danish region showed that specific diseases such as kidney disease, pulmonary disease, and diabetes as well as the co-occurrence of two or more chronic diseases were inversely associated with participation. ${ }^{15}$ The same study found that time elapsed from the most recent disease-specific hospital contact until screening invitation was associated with participation. Thus, women with a contact less than two years before screening relative to two years or more were less likely to participate. ${ }^{15}$ Based on a subset of studies with low risk of bias, a review from 2017 showed that women with comorbidity were less likely to participate. However, the authors emphasize the lack of evidence regarding the effect of individual conditions on participation, because most studies merely dichotomized comorbidity (no versus any comorbidity). ${ }^{12}$

The aim of this study was to investigate morbidity as a predictor of participation in the first round of the national Danish breast cancer-screening program. We assessed morbidity by the 19 individual diseases included in CCI, and by the overall CCI score, which takes into account the severity of the diseases included.

\section{Patients and Methods}

In this cross-sectional study, we included all women invited to the first round (2007-2010) of the national breast cancer screening program in accordance to The Danish Quality Database for Mammography Screening (DQMS). ${ }^{4}$ Each of the five regions in Denmark have their own booking and invitation system. Based on daily updates of addresses, these systems send personal screening invitations including date and place of screening to all women of relevant age residing in the respective region. ${ }^{2}$ Data on date of invitation, screening date, region of residence, and the unique personal identification (CPR) number of each invited woman are transferred from each region to DQMS. The CPR number is registered at every hospital contact in Denmark and permits linkage between different registries. The number also contains information on date of birth. ${ }^{16}$

The Danish National Patient Registry (DNPR) ${ }^{17}$ contains information on all hospitalizations since 1977, and all outpatient activities since 1995. For this study, we retrieved information from the DNPR on diagnoses based on the 10th version of International Classification of Diseases (ICD-10). Data on diagnoses for each woman were extracted ten years back in time from the date of breast cancer screening invitation.

The study is registered at Aarhus University Hospital (2014-54-0922/J. no KEA-2016-18) in accordance with Danish data protection regulations. Ethical approval is not required for non-interventional register-based studies in Denmark.

\section{Study Population}

From the 667,441 women who were invited to the first screening round, we excluded 14,667 women who had a breast cancer diagnosis prior to the invitation (Figure 1). In addition, we excluded 2,771 women who were outside the intended agerange of the screening program at the time of invitation $(\leq 50$ and $\geq 70$ years). Thus, the final study population consisted of 650,003 women. Women who had previously requested not to be invited for the preceding local mammography screening programs in Copenhagen and on Funen were not invited to the national screening program. These women are not included in the DQMS; thus, the number is not available, and they are not part of the present study population. ${ }^{2}$ 


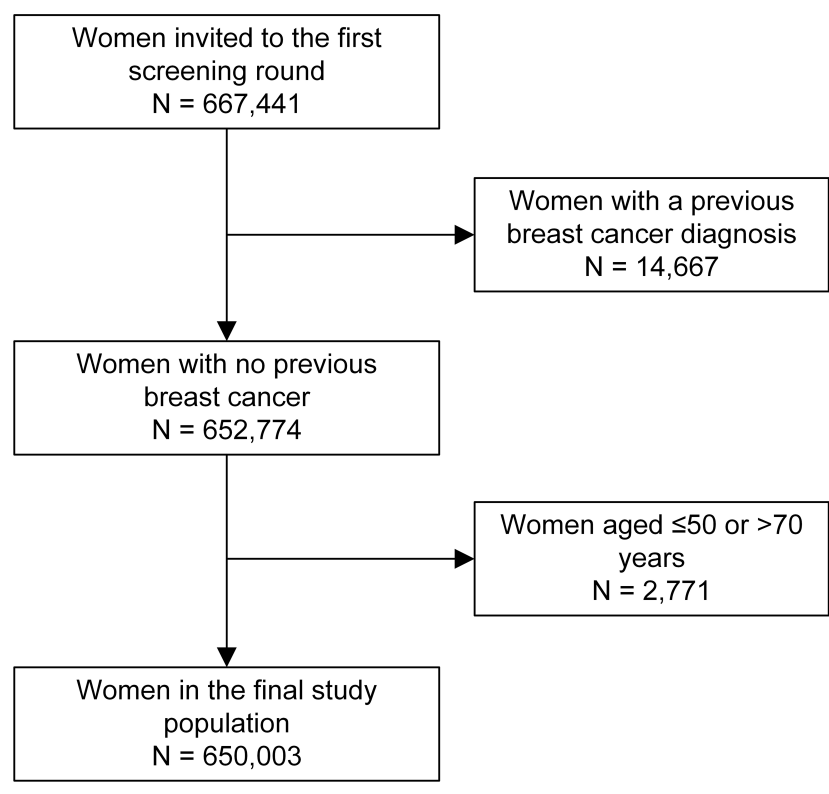

Figure I Flowchart of study population.

\section{Outcome}

Women were considered participants if they were registered in the DQMS with a screening date within the first screening round.

\section{Variables}

We used CCI to quantify overall morbidity. CCI consists of 19 different chronic conditions and each disease is assigned one of the four different weights $(1,2,3$, or 6$)$ (Table 1$)$. The weights were initially developed to predict one-year mortality. A person's overall CCI score takes into account both the number of diseases and the seriousness of each disease. ${ }^{18}$ The total CCI score for women in our study was calculated based on ICD-10 codes retrieved from the DNPR, 10 years back in time. We categorized CCI scores in three groups, 0 , $1-2$, and $\geq 3$. In addition to CCI score, the 19 diseases included in the CCI were evaluated as separate predictors for breast cancer screening participation.

Time elapsed from diagnosis to screening invitation was defined as years following the latest disease-specific diagnosis until date of invitation and was divided into four groups: $<1,1-2,3-4$, and $5-10$ years.

Age was determined at the time of invitation and categorized as 50-54, 55-59, 60-64, and 65-69 years.

Information on the participants' region of residence (the Capital Region of Denmark, the Central Denmark Region, the North Denmark Region, Region Zealand, and Region of Southern Denmark) was included as each region
Table I Included Diagnosis with ICD-10 Code in Charlson Comorbidity Index $(\mathrm{CCl})$ According to Their Respective Weight

\begin{tabular}{|c|c|c|}
\hline $\begin{array}{l}\mathrm{CCl} \\
\text { Weight }\end{array}$ & Diagnosis & ICD-IO Code \\
\hline \multirow[t]{10}{*}{ I } & Myocardial infarction & $121,122,123$ \\
\hline & Congestive heart failure & $150,1110,1130,1132$ \\
\hline & $\begin{array}{l}\text { Peripheral vascular } \\
\text { disease }\end{array}$ & $170,171,172,173,174,177$ \\
\hline & Cerebrovascular disease & 160-169, G45, G46 \\
\hline & Dementia & F00-F03, F05I, G30 \\
\hline & $\begin{array}{l}\text { Chronic pulmonary } \\
\text { disease }\end{array}$ & $\begin{array}{l}J 40-J 47, \text { J60-J67, J684, J70I, J703, J84I, } \\
\text { J920, J96I, J982, J983 }\end{array}$ \\
\hline & Connective tissue disease & $\begin{array}{l}\text { M05, M06, M08, M09, M30, M3।, } \\
\text { M32, M33, M34, M35, M36, D86 }\end{array}$ \\
\hline & Ulcer disease & $\mathrm{K} 22 \mathrm{I}, \mathrm{K} 25-\mathrm{K} 28$ \\
\hline & Mild liver disease & $\begin{array}{l}\mathrm{B} 18, \mathrm{~K} 700-\mathrm{K} 703, \mathrm{~K} 709, \mathrm{~K} 7 \mathrm{I}, \mathrm{K} 73 \text {, } \\
\mathrm{K} 74, \mathrm{~K} 760\end{array}$ \\
\hline & Diabetes I and II & EI00, EIOI, EI09, EIIO, EIII, EII9 \\
\hline \multirow[t]{6}{*}{2} & Hemiplegia & G8I, G82 \\
\hline & $\begin{array}{l}\text { Moderate to severe renal } \\
\text { disease }\end{array}$ & $\begin{array}{l}\text { II2, II3, N00-N05, N07, NII, NI4, } \\
\text { NI7-NI9, Q6I }\end{array}$ \\
\hline & Diabetes with end organ & EI02-EI08, EII2-EII8 \\
\hline & Any tumor ${ }^{\mathrm{a}}$ & $\mathrm{C} 00-C 75^{\mathrm{a}}$ \\
\hline & Leukemia & $\mathrm{C} 91-\mathrm{C} 95$ \\
\hline & Lymphoma & $\mathrm{C} 81-\mathrm{C} 85, \mathrm{C} 88, \mathrm{C} 90, \mathrm{C} 96$ \\
\hline 3 & $\begin{array}{l}\text { Moderate to severe liver } \\
\text { disease }\end{array}$ & $\begin{array}{l}\text { BI50, B160, B162, B190, K704, K72, } \\
\text { K766, } 185\end{array}$ \\
\hline 6 & $\begin{array}{l}\text { Metastatic solid tumor } \\
\text { AIDS }\end{array}$ & $\begin{array}{l}\text { C76-C80 } \\
\text { B2I-B24 }\end{array}$ \\
\hline
\end{tabular}

Note: ${ }^{\mathrm{a} B r e a s t}$ cancer excluded (C50).

have their own booking system and are responsible for sending personal invitations to the eligible women. ${ }^{2}$

\section{Statistical Analysis}

Characteristics of the study population (age, region of residence, and CCI score) were described by frequencies and proportions according to participation status.

To evaluate the crude association between participation and potential predictors (age, region of residence, and CCI score), we used a generalized linear model with a Poisson 
distribution and robust standard errors and estimated crude prevalence proportion ratios (PR) with $95 \%$ confidence intervals (CI). ${ }^{19}$ In the first model, evaluating the association between participation and region of residence and CCI score, respectively, we adjusted for age. In a final model, we mutually adjusted for age, region of residence, and CCI score.

To examine the association between participation and the single diseases included in CCI, we calculated crude PRs as well as PRs adjusted for region of residence and age. In another model, we adjusted for region of residence, age, and presence of any of the other diseases included in CCI. In both, the unadjusted and the adjusted model women without the specific disease of interest served as the reference group. To evaluate if the association varied with respect to recency of diagnosis the analysis was stratified by time since diagnosis $(<1,1-2,3-4$, and 5-10 years).

Data management and statistical analyses were conducted in SAS 9.4 (SAS Institute Inc., Cary, NC, USA).

\section{Results}

The overall participation rate in the first breast cancer screening round in Denmark was 79.8\% (Table 2). Participation decreased with increasing age. Among 65to 69 -year-old women, $76.1 \%$ participated. Participation varied by region from $74.2 \%$ in the Capital Region to $87.1 \%$ in the Region of Southern Denmark. Among women with a CCI score of $\geq 3,64.1 \%$ participated. Among non-participants, $79.5 \%$ had a CCI score of 0 , $16.7 \%$ had a score of $1-2$, and $3.8 \%$ had a CCI score of score $\geq 3$.

The PR for participation adjusted for region of residence and CCI score was 0.95 (95\% CI: 0.95-0.96) for women aged 65-69 years compared with women aged 50-54 years (Table 3, model 2). Relative to women with a CCI score of 0 , the adjusted PRs were 0.96 (95\% CI: 0.95-0.96) for a CCI score of $1-2$ and 0.80 (95\% CI: 0.79-0.81) for a CCI score of $\geq 3$.

The most frequent diseases among the invited women were chronic pulmonary disease $(9.3 \%)$, diabetes type I and II (6.4\%), any tumor (6.2\%), and cerebrovascular disease $(6.2 \%)$ (Table 4$)$. Overall, having one of the diseases included in CCI was inversely associated with participation and this did not change noticeably after adjustment for age and region of residence (Table 4, model 1), but the association attenuated after additional adjustment for the presence of any of the other diseases included in CCI (Table 4, model 2).
Table 2 The Distribution of Participants and Non-Participants Stratified by Age Group, Region, and Charlson Comorbidity Index $(\mathrm{CCl}) . \mathrm{N}=650,003$

\begin{tabular}{|c|c|c|c|}
\hline & $\begin{array}{l}\text { Participants } \\
\text { N (\% } \\
\text { Column) }\end{array}$ & $\begin{array}{l}\text { Non- } \\
\text { Participants } \\
\text { N (\% } \\
\text { Column) }\end{array}$ & $\begin{array}{l}\text { Participation } \\
\% \text { Row }\end{array}$ \\
\hline All women & $519,009(100)$ & $130,994(100)$ & 79.8 \\
\hline $\begin{array}{l}\text { Age group } \\
50-54 \text { years } \\
55-59 \text { years } \\
60-64 \text { years } \\
65-69 \text { years }\end{array}$ & $\begin{array}{l}\mid 44,250(27.8) \\
\mid 33,506(25.7) \\
139,742(26.9) \\
101,5||(19.6)\end{array}$ & $\begin{array}{l}34,890(26.6) \\
30,657(23.4) \\
33,554(25.6) \\
31,893(24.4)\end{array}$ & $\begin{array}{l}80.5 \\
81.3 \\
80.6 \\
76.1\end{array}$ \\
\hline $\begin{array}{l}\text { Region } \\
\text { Capital } \\
\text { Central } \\
\text { Denmark } \\
\text { North } \\
\text { Denmark } \\
\text { Zealand } \\
\text { Southern } \\
\text { Denmark }\end{array}$ & $\begin{array}{l}\text { I37,40| (26.5) } \\
\text { II3,8I8 (2I.9) } \\
57,942(1 \mid .2) \\
87,189(16.8) \\
122,659(23.6)\end{array}$ & $\begin{array}{l}47,704(36.4) \\
30,939(23.6) \\
15,803(12.1) \\
18,438(14.1) \\
18,110(13.8)\end{array}$ & $\begin{array}{l}74.2 \\
78.6 \\
78.6 \\
82.5 \\
87.1\end{array}$ \\
\hline $\begin{array}{l}\mathrm{CCl} \\
0 \\
\mathrm{I}-2 \\
\geq 3\end{array}$ & $\begin{array}{l}437,432(84.3) \\
72,649(14.0) \\
8,928(1.7)\end{array}$ & $\begin{array}{l}104,106(79.5) \\
21,879(16.7) \\
5,009(3.8)\end{array}$ & $\begin{array}{l}80.8 \\
76.9 \\
64.1\end{array}$ \\
\hline
\end{tabular}

Compared with no disease, the PRs for a diagnosis of the most prevalent, but less severe diseases (a CCI weight of one), chronic pulmonary disease, cerebrovascular disease, diabetes I and II were 0.93 (95\% CI: 0.93-0.94), 0.96 (95\% CI: 0.94-0.96), and 0.96 (95\% CI: 0.95-0.97), respectively. Women diagnosed with dementia PR 0.60 (95\% CI: 0.56-0.64) and mild liver disease PR 0.87 (95\% CI: $0.85-0.88$ ) had the lowest participation compared to women without that disease.

Among women with a more severe disease (a CCI weight of two), those diagnosed with hemiplegia had the lowest participation rate and a PR of 0.74 (95\% CI: $0.70-0.79)$. For women with the most frequent disease with CCI weight of two, any tumor, the PR was 0.98 (95\% CI: 0.97-0.99).

Among women with the most severe types of disease (a CCI weight of three or six), a diagnosis of AIDS was associated with the lowest participation rate and a PR of 0.69 (95\% CI: $0.60-0.81)$ and for the most frequent disease, metastatic solid tumor, the PR was 0.73 (95\% CI: $0.70-0.76)$. 
Table 3 Prevalence Proportion Ratio (PR) of Screening by Age Group, Region, and Charlson Comorbidity Index $(\mathrm{CCl})$. N= 650,003

\begin{tabular}{|c|c|c|c|}
\hline & Unadjusted PR (95\% Cl) & Model I PR (95\% Cl) & Model 2 PR (95\% Cl) \\
\hline \multicolumn{4}{|l|}{ Age } \\
\hline $50-54$ years & I (ref) & - & I (ref) \\
\hline $55-59$ years & 1.01 (I.0I-I.0I) & - & 1.01 (I.0I-1.0I) \\
\hline $60-64$ years & $1.00(0.99-1.00)$ & - & $1.01(1.00-1.01)$ \\
\hline $65-69$ years & $0.94(0.94-0.95)$ & - & $0.95(0.95-0.96)$ \\
\hline \multicolumn{4}{|l|}{ Region } \\
\hline Capital & I (ref) & I (ref) & I (ref) \\
\hline Central Denmark & $1.06(1.06-1.06)$ & $1.06(1.05-1.06)$ & $1.06(1.05-1.06)$ \\
\hline North Denmark & $1.06(1.05-1.06)$ & $1.06(1.05-1.06)$ & $1.06(1.05-1.06)$ \\
\hline Zealand & $1.11(1.11-1.12)$ & I.II (I.II-I.I2) & I.II (I.II-I.I2) \\
\hline Southern Denmark & $1.17(1.17-1.18)$ & $1.17(1.17-1.18)$ & $1.17(1.17-1.18)$ \\
\hline \multicolumn{4}{|l|}{$\mathrm{CCl}$} \\
\hline 0 & I (ref) & I (ref) & I (ref) \\
\hline $1-2$ & $0.95(0.95-0.96)$ & $0.96(0.95-0.96)$ & $0.96(0.95-0.96)$ \\
\hline$\geq 3$ & $0.79(0.78-0.80)$ & $0.80(0.79-0.81)$ & $0.80(0.79-0.8 \mathrm{I})$ \\
\hline
\end{tabular}

Notes: Model I: Region and $\mathrm{CCl}$ adjusted for age group. Model 2: Mutually adjusted.

Regardless of severity, for most of all the diseases included in CCI the association with participation varied by time since diagnosis and was most prominent $<1$ year after diagnosis.

\section{Discussion}

Our data indicate that women with a CCI score of one or more were less likely to participate in breast cancer screening compared to women with a CCI score of 0 . Overall, having a single chronic condition was weakly associated with participation. However, some of the less prevalent but more severe diseases; dementia, hemiplegia, metastatic solid tumor, and AIDS were strongly associated with non-participation.

This nationwide study conducted within a tax-funded healthcare system includes all females aged 50-69 years who were invited to the first national breast cancer screening round. Consequently, the study population did not include women with opportunistic screening, thus decreasing the risk of surveillance bias. ${ }^{12,20}$ We did not have the data to evaluate if regional differences in participation might be explained by opportunistic screening. However, as opportunistic screening is rare in Denmark ${ }^{21}$ and we assume it is not differentially related to morbidity, except for previous breast cancer which we excluded, we assume opportunistic screening has little impact on the association between participation and morbidity. ${ }^{5}$ Finally, as we only included data from the prevalence round, participation is less likely to be affected by the women's previous screening experience.
Data on both screening participation and history of hospital diagnoses for each individual were obtained from national registries (the DNPR and the DQMS). Because both participants and non-participants were included in these registries independent of screening participation and screening outcome, the risk of selection bias was minimal. A validation study found a high positive predictive value of the ICD-10 codes included in CCI and registered in the DNPR. ${ }^{22}$ Thus, the registry-based diagnoses are consistent with data in medical records and discharge summaries, which reduces the potential of information bias due to misclassification. In addition, not relying on self-reported data lessens the risk of overestimating the prevalence of morbidity. ${ }^{12,23}$

In our assessment of morbidity, we relied on diagnoses from hospital contacts, hence excluding chronic conditions that only receive medical care in general practice. Further, it should be noted that we did not include information on socioeconomic status, even though some studies have shown it to be a predictor of screening participation ${ }^{6-8,15}$ and associated with multimorbidity. ${ }^{24}$ However, in a study by Jensen et al, the association between multimorbidity and participation was still present after adjusting for socioeconomic status. ${ }^{15}$ It is a limitation that we were not able to evaluate psychiatric morbidity, which is associated with non-participation ${ }^{25}$ and multimorbidity. ${ }^{26}$ If the included women with somatic multimorbidity did not participate in screening due to psychiatric morbidity, we may have 
Table 4 Unadjusted and Adjusted Prevalence Proportion Ratios (PR) for Participation by Selected Diseases and Years Since Diagnosis, Using No Disease as the Reference. Diseases are Separated by Charlson Comorbidity Index (CCl) Weight. N=650,003

\begin{tabular}{|c|c|c|c|c|c|}
\hline & $\begin{array}{l}\text { Participation } \\
\text { Total } \mathbf{N}=5 \text { I } 9,009 \\
\text { N }(\% \text { column) }\end{array}$ & $\begin{array}{l}\text { Non-participation } \\
\text { Total } \mathrm{N}=130,994 \\
\mathrm{~N}(\% \text { column) }\end{array}$ & $\begin{array}{l}\text { Unadjusted } \\
\text { PR (95\% CI) }\end{array}$ & $\begin{array}{l}\text { Model I } \\
\text { PR (95\% CI) }\end{array}$ & $\begin{array}{l}\text { Model } 2 \\
\text { PR (95\% CI) }\end{array}$ \\
\hline \multicolumn{6}{|l|}{ CCI weight I } \\
\hline \multicolumn{6}{|c|}{ Myocardial infarction } \\
\hline Yes & $4,065(0.78)$ & $\mathrm{I}, 403(\mathrm{I} .07)$ & $0.93(0.92-0.95)$ & $0.94(0.92-0.95)$ & $0.98(0.97-1.00)$ \\
\hline$<$ l years & $719(0.14)$ & $260(0.20)$ & $0.92(0.89-0.95)$ & $0.93(0.89-0.96)$ & $0.97(0.94-1.01)$ \\
\hline I-2 years & $993(0.19)$ & $353(0.27)$ & $0.92(0.89-0.95)$ & $0.93(0.90-0.96)$ & $0.97(0.94-1.01)$ \\
\hline $3-4$ years & $857(0.17)$ & $302(0.23)$ & $0.93(0.89-0.96)$ & $0.94(0.91-0.97)$ & $0.98(0.95-1.02)$ \\
\hline $5-10$ years & $1,496(0.29)$ & $488(0.37)$ & $0.94(0.92-0.97)$ & $0.95(0.93-0.97)$ & $0.99(0.97-1.02)$ \\
\hline \multicolumn{6}{|c|}{ Congestive heart failure } \\
\hline Yes & $3,006(0.58)$ & I,492 (I.14) & $0.84(0.82-0.85)$ & $0.85(0.83-0.86)$ & $0.90(0.88-0.92)$ \\
\hline$<$ l years & $808(0.16)$ & $439(0.34)$ & $0.81(0.78-0.84)$ & $0.82(0.79-0.86)$ & $0.88(0.84-0.92)$ \\
\hline I-2 years & $851(0.16)$ & $425(0.32)$ & $0.83(0.80-0.87)$ & $0.85(0.81-0.88)$ & $0.90(0.86-0.93)$ \\
\hline $3-4$ years & $548(0.11)$ & $263(0.20)$ & $0.85(0.81-0.89)$ & $0.85(0.82-0.90)$ & $0.91(0.87-0.95)$ \\
\hline $5-10$ years & $799(0.15)$ & $365(0.28)$ & $0.86(0.83-0.89)$ & $0.86(0.83-0.90)$ & $0.91(0.88-0.95)$ \\
\hline \multicolumn{6}{|c|}{ Peripheral vascular disease } \\
\hline Yes & $6,392(1.23)$ & $2,318(1.77)$ & $0.92(0.91-0.93)$ & $0.92(0.91-0.93)$ & $0.95(0.94-0.96)$ \\
\hline$<$ l years & I,507 (0.29) & $550(0.42)$ & $0.92(0.89-0.94)$ & $0.92(0.90-0.95)$ & $0.96(0.93-0.98)$ \\
\hline I-2 years & $\mathrm{I}, 730(0.33)$ & $717(0.55)$ & $0.88(0.86-0.91)$ & $0.89(0.87-0.91)$ & $0.92(0.90-0.95)$ \\
\hline $3-4$ years & $\mathrm{I}, 196(0.23)$ & $480(0.37)$ & $0.89(0.87-0.92)$ & $0.89(0.87-0.92)$ & $0.93(0.90-0.95)$ \\
\hline $5-10$ years & $1,959(0.38)$ & $571(0.44)$ & $0.97(0.95-0.99)$ & $0.97(0.95-0.99)$ & $0.99(0.97-1.01)$ \\
\hline \multicolumn{6}{|c|}{ Cerebrovascular disease } \\
\hline Yes & $13,228(2.55)$ & $4,810(3.67)$ & $0.92(0.91-0.92)$ & $0.92(0.92-0.93)$ & $0.95(0.94-0.96)$ \\
\hline$<$ I years & $2,750(0.53)$ & $\mathrm{I}, 268(0.97)$ & $0.86(0.84-0.87)$ & $0.86(0.84-0.88)$ & $0.89(0.88-0.91)$ \\
\hline I-2 years & $3,714(0.72)$ & $1,413(1.08)$ & $0.91(0.89-0.92)$ & $0.91(0.90-0.93)$ & $0.94(0.92-0.95)$ \\
\hline $3-4$ years & $2,696(0.52)$ & $918(0.70)$ & $0.93(0.91-0.95)$ & $0.94(0.92-0.96)$ & $0.96(0.95-0.98)$ \\
\hline $5-10$ years & $4,068(0.78)$ & $\mathrm{I}, 2 \mathrm{II}(0.92)$ & $0.96(0.95-0.98)$ & $0.97(0.96-0.98)$ & $0.99(0.97-1.00)$ \\
\hline \multicolumn{6}{|l|}{ Dementia } \\
\hline Yes & $463(0.09)$ & $556(0.42)$ & $0.57(0.53-0.6 I)$ & $0.58(0.54-0.62)$ & $0.60(0.56-0.64)$ \\
\hline$<$ I years & $130(0.03)$ & $181(0.14)$ & $0.52(0.46-0.60)$ & $0.53(0.47-0.61)$ & $0.56(0.49-0.63)$ \\
\hline $\mathrm{I}-2$ years & $139(0.03)$ & $186(0.14)$ & $0.54(0.47-0.61)$ & $0.54(0.48-0.6 I)$ & $0.56(0.50-0.64)$ \\
\hline $3-4$ years & $82(0.02)$ & $97(0.07)$ & $0.57(0.49-0.67)$ & $0.58(0.49-0.68)$ & $0.60(0.52-0.7 I)$ \\
\hline $5-10$ years & $112(0.02)$ & $92(0.07)$ & $0.69(0.61-0.78)$ & $0.70(0.62-0.79)$ & $0.72(0.64-0.8 I)$ \\
\hline \multicolumn{6}{|c|}{ Chronic pulmonary disease } \\
\hline Yes & $19,359(3.73)$ & $7,229(5.52)$ & $0.91(0.90-0.92)$ & $0.92(0.91-0.92)$ & $0.93(0.93-0.94)$ \\
\hline$<$ I years & $4,836(0.93)$ & $2,292(1.75)$ & $0.85(0.83-0.86)$ & $0.85(0.84-0.87)$ & $0.88(0.86-0.89)$ \\
\hline $\mathrm{I}-2$ years & $5,275(1.02)$ & I,938 (I.48) & $0.91(0.90-0.93)$ & $0.92(0.91-0.93)$ & $0.94(0.92-0.95)$ \\
\hline $3-4$ years & $3,615(0.70)$ & $\mathrm{I}, 226(0.94)$ & $0.93(0.92-0.95)$ & $0.94(0.92-0.95)$ & $0.95(0.94-0.97)$ \\
\hline $5-10$ years & $5,633(1.09)$ & I,773 (1.35) & $0.95(0.94-0.96)$ & $0.96(0.95-0.97)$ & $0.97(0.96-0.98)$ \\
\hline \multicolumn{6}{|c|}{ Connective tissue disease } \\
\hline Yes & II,204 (2.16) & $2,708(2.07)$ & $1.01(1.00-1.02)$ & $1.01(1.00-1.02)$ & $1.03(1.02-1.04)$ \\
\hline$<1$ years & $3,175(0.61)$ & $834(0.64)$ & $0.99(0.98-1.01)$ & $1.00(0.99-1.02)$ & $1.02(1.00-1.04)$ \\
\hline $\mathrm{I}-2$ years & $3,264(0.63)$ & $777(0.59)$ & $1.01(1.00-1.03)$ & $1.01(1.00-1.03)$ & $1.03(1.01-1.04)$ \\
\hline $3-4$ years & $2,004(0.39)$ & $439(0.34)$ & $1.03(1.01-1.05)$ & $1.03(1.01-1.05)$ & $1.05(1.03-1.07)$ \\
\hline $5-10$ years & $2,76 I(0.53)$ & $658(0.50)$ & $1.01(1.00-1.03)$ & $1.01(1.00-1.03)$ & $1.03(1.01-1.04)$ \\
\hline \multicolumn{6}{|l|}{ Ulcer disease } \\
\hline Yes & $5,015(0.97)$ & $2,089(1.59)$ & $0.88(0.87-0.90)$ & $0.89(0.87-0.90)$ & $0.92(0.90-0.93)$ \\
\hline$<1$ years & $705(0.14)$ & $340(0.26)$ & $0.84(0.81-0.88)$ & $0.85(0.81-0.88)$ & $0.88(0.84-0.92)$ \\
\hline I-2 years & $\mathrm{I}, 120(0.22)$ & $485(0.37)$ & $0.87(0.85-0.90)$ & $0.87(0.85-0.90)$ & $0.91(0.88-0.94)$ \\
\hline
\end{tabular}

(Continued) 
Table 4 (Continued).

\begin{tabular}{|c|c|c|c|c|c|}
\hline & $\begin{array}{l}\text { Participation } \\
\text { Total N=5 I 9,009 } \\
\text { N (\% column) }\end{array}$ & $\begin{array}{l}\text { Non-participation } \\
\text { Total } N=\mid 30,994 \\
\text { N (\% column) }\end{array}$ & $\begin{array}{l}\text { Unadjusted } \\
\text { PR }(95 \% \mathrm{CI})\end{array}$ & $\begin{array}{l}\text { Model I } \\
\text { PR (95\% CI) }\end{array}$ & $\begin{array}{l}\text { Model } 2 \\
\text { PR (95\% CI) }\end{array}$ \\
\hline $3-4$ years & $1,030(0.20)$ & $444(0.34)$ & $0.87(0.85-0.90)$ & $0.88(0.85-0.91)$ & $0.91(0.88-0.94)$ \\
\hline $5-10$ years & $2,160(0.42)$ & $820(0.63)$ & $0.91(0.89-0.93)$ & $0.91(0.89-0.93)$ & $0.93(0.91-0.95)$ \\
\hline \multicolumn{6}{|c|}{ Mild liver disease } \\
\hline Yes & $3,131(0.60)$ & $\mathrm{I}, 670(\mathrm{I} .27)$ & $0.82(0.80-0.83)$ & $0.82(0.81-0.84)$ & $0.87(0.85-0.88)$ \\
\hline$<$ I years & $804(0.15)$ & $520(0.40)$ & $0.76(0.73-0.79)$ & $0.77(0.73-0.80)$ & $0.82(0.78-0.86)$ \\
\hline $\mathrm{I}-2$ years & $815(0.16)$ & $468(0.36)$ & $0.79(0.76-0.83)$ & $0.80(0.77-0.83)$ & $0.84(0.8 \mathrm{I}-0.88)$ \\
\hline $3-4$ years & $597(0.12)$ & $304(0.23)$ & $0.83(0.79-0.87)$ & $0.83(0.80-0.87)$ & $0.87(0.83-0.91)$ \\
\hline $5-10$ years & $915(0.18)$ & $378(0.29)$ & $0.89(0.85-0.92)$ & $0.89(0.86-0.93)$ & $0.92(0.89-0.96)$ \\
\hline \multicolumn{6}{|c|}{ Diabetes I and II } \\
\hline Yes & I3,429 (2.59) & $4,974(3.80)$ & $0.91(0.90-0.92)$ & $0.91(0.91-0.92)$ & $0.96(0.95-0.97)$ \\
\hline$<$ I years & $3,875(0.75)$ & $\mathrm{I}, 603(1.22)$ & $0.88(0.87-0.90)$ & $0.89(0.87-0.90)$ & $0.94(0.93-0.96)$ \\
\hline I-2 years & $4,479(0.86)$ & $1,530(1.17)$ & $0.93(0.92-0.95)$ & $0.93(0.92-0.94)$ & $0.98(0.96-0.99)$ \\
\hline $3-4$ years & $2,579(0.50)$ & $886(0.68)$ & $0.93(0.91-0.95)$ & $0.93(0.92-0.95)$ & $0.98(0.96-1.00)$ \\
\hline $5-10$ years & $2,496(0.48)$ & $955(0.73)$ & $0.90(0.89-0.92)$ & $0.91(0.89-0.93)$ & $0.94(0.93-0.96)$ \\
\hline \multicolumn{6}{|l|}{ CCI weight 2} \\
\hline \multicolumn{6}{|l|}{ Hemiplegia } \\
\hline Yes & $407(0.08)$ & $309(0.24)$ & $0.7 I(0.67-0.76)$ & $0.7 I(0.67-0.76)$ & $0.74(0.70-0.79)$ \\
\hline$<$ I years & $92(0.02)$ & $95(0.07)$ & $0.62(0.53-0.7 \mathrm{I})$ & $0.62(0.54-0.72)$ & $0.65(0.57-0.75)$ \\
\hline I-2 years & $118(0.02)$ & $76(0.06)$ & $0.76(0.68-0.85)$ & $0.77(0.69-0.86)$ & $0.80(0.72-0.89)$ \\
\hline $3-4$ years & $93(0.02)$ & $67(0.05)$ & $0.73(0.64-0.83)$ & $0.72(0.64-0.83)$ & $0.76(0.67-0.86)$ \\
\hline $5-10$ years & $104(0.02)$ & $71(0.05)$ & $0.74(0.66-0.84)$ & $0.74(0.66-0.84)$ & $0.77(0.68-0.87)$ \\
\hline \multicolumn{6}{|c|}{ Moderate to severe renal disease } \\
\hline Yes & $2,495(0.48)$ & $\mathrm{I}, 074(0.82)$ & $0.87(0.86-0.89)$ & $0.88(0.86-0.90)$ & $0.93(0.91-0.95)$ \\
\hline$<1$ years & $731(0.14)$ & $455(0.35)$ & $0.77(0.74-0.81)$ & $0.78(0.74-0.8 I)$ & $0.83(0.79-0.87)$ \\
\hline I-2 years & $721(0.14)$ & $266(0.20)$ & $0.91(0.88-0.95)$ & $0.92(0.88-0.95)$ & $0.97(0.93-1.01)$ \\
\hline $3-4$ years & $44 \mid(0.09)$ & $162(0.12)$ & $0.92(0.87-0.96)$ & $0.92(0.88-0.97)$ & $0.97(0.92-1.01)$ \\
\hline $5-10$ years & $602(0.12)$ & $191(0.15)$ & $0.95(0.91-0.99)$ & $0.96(0.92-0.99)$ & $0.98(0.95-1.02)$ \\
\hline \multicolumn{6}{|c|}{ Diabetes with end organ } \\
\hline Yes & $5,144(0.99)$ & $2,467(1.88)$ & $0.84(0.83-0.86)$ & $0.85(0.84-0.87)$ & $0.91(0.90-0.93)$ \\
\hline$<1$ years & $\mathrm{I}, 37 \mathrm{I}(0.26)$ & $789(0.60)$ & $0.79(0.77-0.82)$ & $0.8 \mathrm{I}(0.78-0.83)$ & $0.88(0.85-0.91)$ \\
\hline $\mathrm{I}-2$ years & $\mathrm{I}, 622(0.3 \mathrm{I})$ & $779(0.59)$ & $0.84(0.82-0.87)$ & $0.85(0.83-0.88)$ & $0.91(0.89-0.94)$ \\
\hline $3-4$ years & $1,210(0.23)$ & $50 \mathrm{I}(0.38)$ & $0.88(0.86-0.91)$ & $0.90(0.87-0.92)$ & $0.95(0.92-0.98)$ \\
\hline $5-10$ years & $941(0.18)$ & $398(0.30)$ & $0.88(0.85-0.91)$ & $0.88(0.85-0.92)$ & $0.93(0.90-0.97)$ \\
\hline \multicolumn{6}{|l|}{ Any tumor ${ }^{a}$} \\
\hline Yes & 14,237 (2.74) & $4,585(3.50)$ & $0.95(0.94-0.95)$ & $0.95(0.94-0.96)$ & $0.98(0.97-0.99)$ \\
\hline$<1$ years & $3,807(0.73)$ & $2,036(1.55)$ & $0.81(0.80-0.83)$ & $0.82(0.81-0.84)$ & $0.86(0.85-0.88)$ \\
\hline I-2 years & $3,842(0.74)$ & $\mathrm{I}, 002(0.76)$ & $0.99(0.98-1.01)$ & $1.00(0.98-1.01)$ & $1.03(1.01-1.04)$ \\
\hline $3-4$ years & $2,573(0.50)$ & $609(0.46)$ & $1.01(0.99-1.03)$ & $1.01(1.00-1.03)$ & $1.03(1.01-1.05)$ \\
\hline $5-10$ years & $4,015(0.77)$ & $938(0.72)$ & $1.01(1.00-1.03)$ & $1.02(1.00-1.03)$ & $1.03(1.02-1.05)$ \\
\hline \multicolumn{6}{|l|}{ Leukemia } \\
\hline Yes & $503(0.10)$ & $160(0.12)$ & $0.95(0.91-0.99)$ & $0.96(0.92-1.00)$ & $0.97(0.93-1.01)$ \\
\hline$<1$ years & $194(0.04)$ & $83(0.06)$ & $0.88(0.81-0.95)$ & $0.88(0.81-0.95)$ & $0.90(0.83-0.97)$ \\
\hline I-2 years & $198(0.04)$ & $45(0.03)$ & $1.02(0.96-1.08)$ & $1.03(0.97-1.10)$ & $1.04(0.98-1.10)$ \\
\hline $3-4$ years & $52(0.01)$ & $14(0.01)$ & $0.99(0.87-1.12)$ & $1.00(0.88-1.13)$ & $1.02(0.90-1.16)$ \\
\hline $5-10$ years & $59(0.01)$ & $18(0.01)$ & $0.96(0.85-1.09)$ & $0.97(0.86-1.09)$ & $0.98(0.87-1.10)$ \\
\hline \multicolumn{6}{|l|}{ Lymphoma } \\
\hline Yes & $\mathrm{I}, 234(0.24)$ & $463(0.35)$ & $0.91(0.88-0.94)$ & $0.92(0.89-0.94)$ & $0.95(0.92-0.98)$ \\
\hline$<1$ years & $431(0.08)$ & $219(0.17)$ & $0.83(0.79-0.88)$ & $0.83(0.79-0.88)$ & $0.86(0.82-0.91)$ \\
\hline
\end{tabular}

(Continued) 
Table 4 (Continued).

\begin{tabular}{|c|c|c|c|c|c|}
\hline & $\begin{array}{l}\text { Participation } \\
\text { Total } N=5 \text { | } 9,009 \\
N \text { ( } \% \text { column) }\end{array}$ & $\begin{array}{l}\text { Non-participation } \\
\text { Total } \mathrm{N}=130,994 \\
\mathrm{~N}(\% \text { column) }\end{array}$ & $\begin{array}{l}\text { Unadjusted } \\
\text { PR }(95 \% \mathrm{CI})\end{array}$ & $\begin{array}{l}\text { Model I } \\
\text { PR (95\% CI) }\end{array}$ & $\begin{array}{l}\text { Model } 2 \\
\text { PR }(95 \% \mathrm{Cl})\end{array}$ \\
\hline I-2 years & $421(0.08)$ & $133(0.10)$ & $0.95(0.91-1.00)$ & $0.96(0.91-1.00)$ & $1.00(0.95-1.04$ \\
\hline $3-4$ years & $190(0.04)$ & $57(0.04)$ & $0.96(0.90-1.03)$ & $0.98(0.91-1.05)$ & $1.02(0.95-1.09$ \\
\hline $5-10$ years & $192(0.04)$ & $54(0.04)$ & $0.98(0.91-1.04)$ & $0.98(0.92-1.05)$ & $1.01(0.95-1.08$ \\
\hline \multicolumn{6}{|l|}{$\mathrm{CCl}$ weight 3} \\
\hline \multicolumn{6}{|c|}{ Moderate to severe liver disease } \\
\hline Yes & $577(0.11)$ & $397(0.30)$ & $0.74(0.70-0.78)$ & $0.75(0.7 I-0.79)$ & $0.87(0.82-0.92$ \\
\hline$<1$ years & $191(0.04)$ & $156(0.12)$ & $0.69(0.63-0.76)$ & $0.69(0.63-0.76)$ & $0.81(0.74-0.89$ \\
\hline $\mathrm{I}-2$ years & $177(0.03)$ & $109(0.08)$ & $0.77(0.7 I-0.85)$ & $0.78(0.7 \mathrm{I}-0.85)$ & $0.91(0.83-0.99$ \\
\hline $3-4$ years & $101(0.02)$ & $69(0.05)$ & $0.74(0.66-0.84)$ & $0.75(0.66-0.85)$ & $0.88(0.77-0.99$ \\
\hline $5-10$ years & $108(0.02)$ & $63(0.05)$ & $0.79(0.7 I-0.89)$ & $0.80(0.71-0.90)$ & $0.92(0.82-1.02$ \\
\hline \multicolumn{6}{|l|}{ CCl weight 6} \\
\hline \multicolumn{6}{|c|}{ Metastatic solid tumor } \\
\hline Yes & $\mathrm{I}, 08 \mathrm{I}(0.2 \mathrm{I})$ & $846(0.65)$ & $0.70(0.67-0.73)$ & $0.70(0.68-0.73)$ & $0.73(0.70-0.76$ \\
\hline$<$ l years & $370(0.07)$ & $510(0.39)$ & $0.53(0.49-0.57)$ & $0.53(0.49-0.57)$ & $0.54(0.50-0.59)$ \\
\hline I-2 years & $294(0.06)$ & $180(0.14)$ & $0.78(0.72-0.83)$ & $0.78(0.73-0.84)$ & $0.81(0.75-0.87)$ \\
\hline $3-4$ years & $176(0.03)$ & $71(0.05)$ & $0.89(0.82-0.97)$ & $0.89(0.82-0.96)$ & $0.92(0.85-1.00)$ \\
\hline $5-10$ years & $24 I(0.05)$ & $85(0.07)$ & $0.93(0.87-0.99)$ & $0.93(0.87-0.99)$ & $0.95(0.89-1.02$ \\
\hline \multicolumn{6}{|l|}{ AIDS } \\
\hline Yes & $76(0.02)$ & $69(0.05)$ & $0.66(0.56-0.77)$ & $0.66(0.57-0.78)$ & $0.69(0.60-0.81)$ \\
\hline$<$ I years & $24(0.01)$ & $28(0.02)$ & $0.58(0.43-0.78)$ & $0.58(0.44-0.78)$ & $0.62(0.47-0.82)$ \\
\hline I-2 years & $34(0.01)$ & $21(0.02)$ & $0.77(0.63-0.95)$ & $0.79(0.64-0.97)$ & $0.82(0.67-1.01)$ \\
\hline $3-4$ years & $8(0.00)$ & $\mathrm{II}(0.0 \mathrm{I})$ & $0.53(0.31-0.89)$ & $0.54(0.32-0.91)$ & $0.55(0.32-0.92$ \\
\hline $5-10$ years & $10(0.00)$ & $9(0.01)$ & $0.66(0.43-1.01)$ & $0.67(0.43-1.03)$ & $0.68(0.44-1.05)$ \\
\hline
\end{tabular}

Notes: Model I: Adjusted for region and age group. Model 2: Adjusted for region, age group, and prevalence of any other CCl-disease. ${ }^{a}$ Breast cancer excluded. Reference is no disease.

overestimated the association between somatic morbidity and participation.

In a US study, Kiefe et al found that one incremental increase in CCI score meant $17 \%$ less likelihood of participation in breast cancer screening. In comparison, we did not analyze the CCI score as a continuous variable, but in line with their findings, we found that participation decreased with a higher CCI score. Furthermore, Kiefe et al found that for each 10-year increase in age, the likelihood of participation decreased by $12 \%$. Thus, older women were less likely to participate in screening. This was also the case in our study for the oldest women invited (65-69 years). ${ }^{14}$

In a study of female residents from one Danish region, Jensen et al found that morbidity was associated with nonparticipation in screening, which increased with each additional disease compared to no disease. This result corresponds to our finding that women with a high CCI score were less likely to participate. Overall, our data indicate that only a more recent diagnosis $(<1$ year before screening invitation) was appreciably associated with participation, which is in line with the study by Jensen et al. ${ }^{15}$ However, they found that women with previous cancer even 2-10 years before screening invitation had a lower participation rate whereas we only found lower participation among women diagnosed with cancer (any tumor) within one year prior to screening invitation.

Kiefe et al point out that patients with multimorbidity can increase the awareness of the general practitioner (GP) and that the GP might advise against screening. This could be due to reduced life expectancy or quality of life caused by the women's primary condition. ${ }^{14}$ Another study suggests that women with severe multimorbidity might not have the same advantage of early detection of cancer, as women with no concurrent conditions. ${ }^{27}$ This could discourage women from participating in screening.

Our study indicates that women with a high CCI score or a single severe chronic disease included in CCI are less likely to participate in breast cancer screening. However, they represent a small proportion of all non-participating women. On the other hand, women with more common diseases, which are 
weakly associated with non-participation, represent a notable proportion of the non-participating group.

This schism is part of the prevention paradox where the benefit of an intervention not only relies on each individual benefit but also on the prevalence of the risk factor. ${ }^{28}$ If participation campaigns aim to maximize participation in women with high risk of non-participation due to morbidity, the screening program as a whole may not benefit substantially since this high-risk group represents a low prevalence group. In addition, these women might not benefit individually from the screening program due to their current condition, and their potential personal benefit from screening might not outweigh the potential difficulties. ${ }^{14,27}$ From a societal point of view, the greatest benefit might be gained from an effort to maximize participation among women with less severe although more common morbidities, such as women with diabetes or chronic pulmonary disease.

\section{Conclusion}

Women with a high morbidity score or a severe single chronic condition are less likely to participate in breast cancer screening compared to women without disease. However, these women account for a small proportion of all nonparticipating women. Thus, it might be most beneficial to maximize breast cancer screening participation in women with less severe although more common morbidities.

\section{Acknowledgments}

We thank members of the Steering Group for The Danish Quality Database of Mammography Screening for their effort in monitoring the screening program and Statistician Frank Mehnert for initial data management. The study was funded by the Danish Cancer Society, R134-A8561.

\section{Disclosure}

The authors declare that there is no conflict of interest.

\section{References}

1. Engholm G, Ferlay J, Christensen N, et al. NORDCAN-a Nordic tool for cancer information, planning, quality control and research. Acta Oncol. 2010;49(5):725-736. doi:10.3109/02841861003782017

2. Langagergaard V, Garne JP, Vejborg I, et al. Existing data sources for clinical epidemiology: the Danish quality database of mammography screening. Clin Epidemiol. 2013;5:81-88. doi:10.2147/CLEP.S40484

3. Perry N, Broeders M, de Wolf C, Tornberg S, Holland R, von Karsa L. European guidelines for quality assurance in breast cancer screening and diagnosis. Fourth edition-summary document. Ann Oncol. 2008;19(4):614-622. doi:10.1093/annonc/mdm481
4. Mikkelsen EM, Njor SH, Vejborg I. Danish quality database for mammography screening. Clin Epidemiol. 2016;8:661-666. doi:10.2147/CLEP.S99467

5. Lynge E, Bak M, von Euler-chelpin M, et al. Outcome of breast cancer screening in Denmark. BMC Cancer. 2017;17(1):897-899. doi:10.1186/s12885-017-3929-6

6. Khaliq W, Aamar A, Wright SM. Predictors of non-adherence to breast cancer screening among hospitalized women. PLoS One. 2015;10(12):e0145492. doi:10.1371/journal.pone.0145492

7. Martinez-Huedo MA, Lopez de Andres A, Hernandez-Barrera V, Carrasco-Garrido P, Martinez HD, Jimenez-Garcia R. Adherence to breast and cervical cancer screening in Spanish women with diabetes: associated factors and trend between 2006 and 2010. Diabetes Metab. 2012;38(2):142-148. doi:10.1016/j.diabet.2011.09.007

8. Martin-Lopez R, Jimenez-Garcia R, Lopez-de-Andres A, et al. Inequalities in uptake of breast cancer screening in Spain: analysis of a cross-sectional national survey. Public Health. 2013;127 (9):822-827. doi:10.1016/j.puhe.2013.03.006

9. von Euler-chelpin M, Olsen AH, Njor S, et al. Does educational level determine screening participation? Eur J Cancer Prev. 2008;17 (3):273-278. doi:10.1097/CEJ.0b013e3282f0c017

10. Tugwell P, Knottnerus JA. Multimorbidity and Comorbidity are now separate MESH headings. J Clin Epidemiol. 2019;105:vi-viii. doi:10.1016/j.jclinepi.2018.11.019

11. Sørensen HT. Multimorbidity and cancer outcomes: a for more research. Clin Epidemiol. 2013;5(Suppl 1):1-2. doi:10.2147/CLEP. S47149

12. Diaz A, Kang J, Moore SP, et al. Association between comorbidity and participation in breast and cervical cancer screening: a systematic review and meta-analysis. Cancer Epidemiol. 2017;47:7-19. doi:10.1016/j.canep.2016.12.010

13. Deshpande AD, McQueen A, Coups EJ. Different effects of multiple health status indicators on breast and colorectal cancer screening in a nationally representative US sample. Cancer Epidemiol. 2012;36 (3):270-275. doi:10.1016/j.canep.2011.10.001

14. Kiefe CI, Funkhouser E, Fouad MN, May DS. Chronic disease as a barrier to breast and cervical cancer screening. J Gen Intern Med. 1998;13(6):357-365. doi:10.1046/j.1525-1497.1998. 00115.x

15. Jensen LF, Pedersen AF, Andersen B, Vestergaard M, Vedsted P. Non-participation in breast cancer screening for women with chronic diseases and multimorbidity: a population-based cohort study. $B M C$ Cancer. 2015;15:. doi:10.1186/s12885-015-1829-1

16. Schmidt M, Pedersen L, Sorensen HT. The Danish civil registration system as a tool in epidemiology. Eur J Epidemiol. 2014;29 (8):541-549. doi:10.1007/s10654-014-9930-3

17. Schmidt M, Schmidt SAJ, Sandegaard JL, Ehrenstein V, Pedersen L, Sørensen HT. The Danish National Patient Registry: a review of content, data quality, and research potential. Clin Epidemiol. 2015;7:449. doi:10.2147/CLEP.S91125

18. Charlson ME, Pompei P, Ales KL, MacKenzie CR. A new method of classifying prognostic comorbidity in longitudinal studies: development and validation. $J$ Chronic Dis. 1987;40(5):373-383. doi:10.1016/0021-9681(87)90171-8

19. Barros AJ, Hirakata VN. Alternatives for logistic regression in cross-sectional studies: an empirical comparison of models that directly estimate the prevalence ratio. BMC Med Res Methodol. 2003;3:21. doi:10.1186/1471-2288-3-21

20. Miles A, Cockburn J, Smith RA, Wardle J. A perspective from countries using organized screening programs. Cancer. 2004;101(5 Suppl):1201-1213. doi:10.1002/cncr.20505

21. Jensen A, Olsen AH, von Euler-chelpin M, Njor SH, Vejborg I, Lynge E. Do nonattenders in mammography screening programmes seek mammography elsewhere? Int J Cancer. 2005;113(3):464-470. doi:10.1002/ijc.20604 
22. Thygesen SK, Christiansen CF, Christensen S, Lash TL, Sørensen HT. The predictive value of ICD-10 diagnostic coding used to assess Charlson comorbidity index conditions in the population-based Danish National Registry of Patients. BMC Med Res Methodol. 2011;11:83. doi:10.1186/1471-2288-11-83

23. Corser W, Sikorskii A, Olomu A, Stommel M, Proden C, HolmesRovner M. Concordance between comorbidity data from patient self-report interviews and medical record documentation. $B M C$ Health Serv Res. 2008;8:85. doi:10.1186/1472-6963-8-85

24. Barnett K, Mercer SW, Norbury M, Watt G, Wyke S, Guthrie B. Epidemiology of multimorbidity and implications for health care, research, and medical education: a cross-sectional study. Lancet. 2012;380(9836):37-43. doi:10.1016/S0140-6736(12)60240-2
25. Jensen LF, Pedersen AF, Bech BH, Andersen B, Vedsted P. Psychiatric morbidity and non-participation in breast cancer screening. Breast (Edinburgh, Scotland). 2016;25:38-44. doi:10.1016/j.breast.2015.10.002

26. De Hert M, Correll CU, Bobes J, et al. Physical illness in patients with severe mental disorders. I. Prevalence, impact of medications and disparities in health care. World Psychiatry. 2011;10(1):52-77.

27. Satariano WA, Ragland DR. The effect of comorbidity on 3-year survival of women with primary breast cancer. Ann Intern Med. 1994;120 (2):104-110. doi:10.7326/0003-4819-120-2-199401150-00002

28. Rose G. Strategy of prevention: lessons from cardiovascular disease. Br Med J (Clin Res Ed). 1981;282(6279):1847-1851. doi:10.1136/ bmj.282.6279.1847
Clinical Epidemiology

\section{Publish your work in this journal}

Clinical Epidemiology is an international, peer-reviewed, open access, online journal focusing on disease and drug epidemiology, identification of risk factors and screening procedures to develop optimal preventative initiatives and programs. Specific topics include: diagnosis, prognosis, treatment, screening, prevention, risk factor modification,

Submit your manuscript here: https://www.dovepress.com/clinical-epidemiology-journal

\section{Dovepress}

systematic reviews, risk \& safety of medical interventions, epidemiology \& biostatistical methods, and evaluation of guidelines, translational medicine, health policies \& economic evaluations. The manuscript management system is completely online and includes a very quick and fair peer-review system, which is all easy to use. 